\title{
Investment dilemmas in the implementation of gasification technology in Poland
}

ABSTRACT: Gasification technology is often seen as a synonym for the clean and efficient processing of solid fuels into combustible gas containing mainly carbon monoxide and hydrogen, the two basic components of synthesis gas. First and foremost, the facts that gas may be cleaned and that a mixture with any composition may be prepared in a relatively easy and inexpensive manner influence the possibility of using gas produced in the energy and chemical industries. In the energy industry, gas may be used directly to generate heat and electricity in the systems of a steam power plant or in combined cycle systems. It is also possible to effectively separate $\mathrm{CO}_{2}$ from the system. However, in chemistry, synthesis gas may be used to produce hydrogen, methanol, synthetic gasolines, and other chemical products. The raw material for gasification is full-quality pulverized coal, but a possibility of processing low-quality sludges, combustible fractions separated from municipal waste as well as industrial waste also exists. Despite such a wide application of technology and undoubted advantages thereof, making investment decisions is still subject to high uncertainty. The paper presents the main technological applications of gasification and analyzes the economic effectiveness thereof. In this context, significant challanges for the industrial implementation of this technology are discussed.

KEYWORDS: gasification, gasification technologies, coal

\footnotetext{
1 Institute for Chemical Processing of Coal - Zabrze, Poland; e-mail: msc@ichpw.pl

2 AGH University of Science and Technology, Department of Energy and Fuels, Kraków, Poland; e-mail: chmielniak@agh.edu.pl

${ }^{3}$ AGH University of Science and Technology, Department of Management, Kraków, Poland; e-mail: kkwasnie@zarz.agh.edu.pl
} 


\section{Introduction}

Gasification technology is often perceived as a synonym for the clean and efficient processing of fuels into combustible gas containing mainly carbon monoxide and hydrogen, the two basic components of synthesis gas. First and foremost, the fact that gas may be cleaned and that a mixture with any composition may be prepared in a relatively easy and inexpensive manner results in an extensive possibility of using gas produced in the energy and chemical industries. In the energy industry, gas may be used directly to generate heat and electricity in the systems of a steam power plant or in combined cycle systems. It is also possible to effectively separate $\mathrm{CO}_{2}$ from the system. However, in chemistry, synthesis gas may be used to produce hydrogen, methanol, synthetic gasolines and other chemical products (Ściążko and Chmielniak 2012).

The raw material for gasification may be full-valued pulverized coal as well as the exist for processing biomass fuels (Chmielniak and Ściążko 2003), low-quality sludges, combustible fractions separated from municipal waste as well as industrial waste.

Essentially there is no limitation for the scale of a gasification unit. Structures using fixed or fluid bed gasifiers are used for municipal and industrial waste processing. Coal sludges and poor coals are most preferably gasified in a fluidized bed, whereas the gasification of full-valued pulverized coals is best carried out in entrained bed gasifiers.

The main driving forces behind the development of coal gasification technologies are:

$\checkmark$ Global imbalance of access to natural gas and oil resources as well as related political tensions.

$\checkmark$ Volatile prices of fossil fuels in some countries, including prices of natural gas and crude oil, and in particular the growing disproportion between coal prices and gas and oil prices.

$\checkmark$ Lower global gas and oil resources and, as a consequence, predicted the faster depletion of such raw materials.

$\downarrow$ Substitution of imported natural gas for chemical production which increases the energy security of countries with coal resources.

$\checkmark$ Environmental protection; specificity of the process allows for separation of harmful substances at high efficiency and relatively low cost, which, in particular, is important in the development of so-called zero-emission energy.

In the case of the development of waste gasification technology, the above motivations primarily include the possibility of energy and chemical use of combustible substances contained in these streams. This is one of the few options for the practical implementation of principles of the closed-circuit economy.

Despite such a wide potential of technology application and undoubted advantages thereof, making investment decisions is still subject to high uncertainty. This mainly applies to outlays incurred on CAPEX and OPEX, which then affect the costs of manufacturing the final product.

The paper presents the main technological applications of gasification and analyzes the economic effectiveness thereof. In this context, important conditions which often constitute a serious barrier to implementation of this technology are discussed. 


\section{Classification of applications and the type of gasifiers}

In terms of their construction, gasifiers fall into three basic types depending on the fuel flow structure in the reaction zone (Chmielniak 2014) (Fig. 1): entrained flow gasifiers, fluidized bed gasifiers, and fixed bed-moving bed gasifiers. The development of modern coal gasification technologies is first and foremost connected with the process intensification and for this reason fluidized bed and entrained flow gasifiers are considered to be most promising on a large scale as they allow for high heat and mass transfer coefficients to be obtained as well as the tar content in the produced process gas to be minimized.

Among the coal gasification technologies in the entrained flow and fluidized bed gasifiers, the latter has been better developed and verified on a commercial scale. It constitutes the basis of virtually all modern large-scale production systems integrated with coal gasification, including IGCC (Integrated Gasification Combined Cycle) energy production systems.

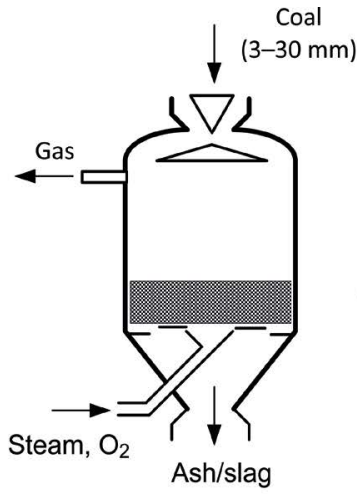

Fixed bed-fluid bed gasifier

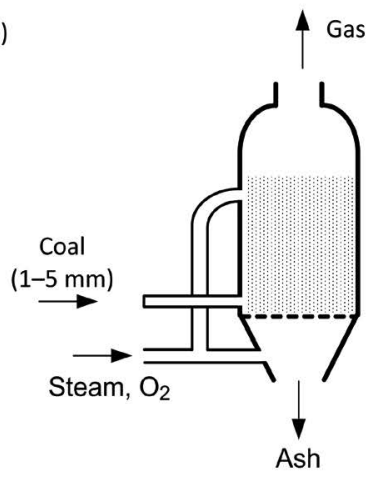

Fluidized bed gasifier

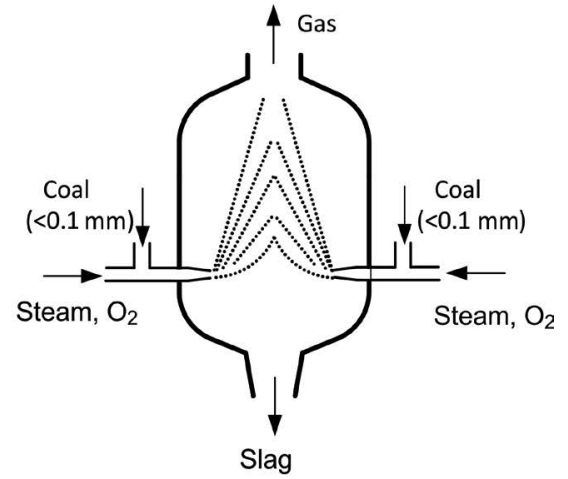

Entrained flow gasifier

Fig. 1. Gasification reactor types (Chmielniak 2014)

Rys. 1. Procesowe rozwiązania reaktorów zgazowania

In the case of gasification of municipal and industrial waste, due to the difficulty of shredding control prior to the gasification process, fixed bed-moving bed gasifiers are dominant. While such solutions are developed primarily for energy purposes, a chemical direction has also been considered in recent years. In the case of the chemical direction, technological development is expected to result in full-scale implementation of chemical production systems, e.g. for methanol and its derivatives, and in the case of the energy direction, to highly efficient local electricity generation systems based on, for instance, internal combustion engines, Sterling engines, or fuel cells. In most cases, systems which use combustible waste in the chemical direction are only 
being developed or are at the early stage of demonstration. For this reason, it is difficult to discuss economically viable technologies in an unambiguous manner due to the difficulty of assessing the risks associated therewith.

\section{Investment risks of coal and waste gasification}

In setting out to analyze the technical potential of the offered solutions, first of all, the key elements of undertaking the investment risk should be taken into account. The basic risk factors and important related issues, which, if not taken into account, may lead to a project failure, are shown below. These involve:

$\downarrow$ Supply of raw materials and technological safety:

- Has the availability of the raw material for processing been assessed in the perspective of the life cycle of the system?

$\downarrow$ Have the proposed technologies been sufficiently tested for the raw material that we intend to process?

\ Have the quality characteristics of the raw material been taken into account when selecting the technology?

Is the selected technology among the most advanced applications?

$\downarrow$ Emission capacity and impact on the environment:

- Have the offered emission indicators been obtained for a similar scale system and for similar fuel?

Does the system generate solid or liquid waste?

$\downarrow$ Investment and operating costs:

$\downarrow$ Does the analysis include all basic components of investment costs?

$\downarrow$ Does the analysis include all basic components of operating costs?

\ Has the operating availability been appropriately adopted?

- Are planned maintenance shutdowns and their costs taken into account on the basis of reference systems?

$\downarrow$ General:

4 Are the location conditions favorable for obtaining an environmental permit?

$\downarrow$ Do the guarantees cover relevant process parameters and the operation of process facilities?

Consideration of the above factors should be reflected in the methodology for assessing various coal or waste gasification technologies in order to indicate in a reliable manner the least risky business technologies or indicate higher risk technologies, which will allow us to gain a competitive advantage in the near future. 


\section{The state of technology development}

\subsection{Coal gasification}

The dynamic development of gasification technology was initiated in the second half of the twentieth century, and another significant acceleration was observed from the 2010, as a result of investments carried out mainly in China.

This has been confirmed by the published data in the period from 2010-2017, in which a $144 \%$ increase in the production of process gas took place. Taking the production capacity of the built and planned systems into account, the increase in production in relation to the data from 2010 was $297 \%$ and $461 \%$ respectively. Table 1 presents a summary of the number of gasifiers for subsequent database updates on industrial gasification systems in the world (Higman 2013, 2017).

TABLE 1. Summary of gasification systems and gasifiers, 1999-2013 (Higman 2013, 2017)

TABELA 1. Zestawienie instalacji i reaktorów zgazowania, lata 1999-2013

\begin{tabular}{|c|c|c|c|c|c|c|}
\hline $\begin{array}{c}\text { Year } \\
\text { of update }\end{array}$ & $\begin{array}{c}\text { Existing units } \\
\text { and systems/ } \\
\text { gasifiers }\end{array}$ & $\begin{array}{c}\text { Built units } \\
\text { and systems/ } \\
\text { /gasifiers }\end{array}$ & $\begin{array}{c}\text { Planned units } \\
\text { and systems/ } \\
\text { /gasifiers }\end{array}$ & $\begin{array}{c}\text { Existing } \\
\text { systems, } \\
\mathrm{GW}_{\text {th }}\end{array}$ & $\begin{array}{c}\text { Built } \\
\text { systems, } \\
\mathrm{GW}_{\text {th }}\end{array}$ & $\begin{array}{c}\text { Planned } \\
\text { systems, } \\
\mathrm{GW}_{\text {th }}\end{array}$ \\
\hline 1999 & $128 / 366$ & b.d. & $33 / 48$ & 42.7 & b.d. & 18.2 \\
\hline 2001 & $131 / 409$ & b.d. & $32 / 59$ & 43.3 & b.d. & 24.5 \\
\hline 2004 & $117 / 385$ & b.d. & $38 / 66$ & 43 & b.d. & 25.3 \\
\hline 2007 & $144 / 427$ & b.d. & paź. 34 & 56.2 & b.d. & 36.5 \\
\hline 2010 & $192 / 405$ & lis. 17 & $37 / 76$ & 70.8 & 10.9 & 40.4 \\
\hline 2013 & $234 / 618$ & $61 / 202$ & $98 / 550$ & 104.7 & 63.4 & 84.0 \\
\hline 2017 & $379 / 938$ & $131 / 348$ & $146 / 734$ & 173 & 108 & 116.0 \\
\hline
\end{tabular}

Analysis of the current state of development of industrial gasification systems leads to the following assumptions (Higman 2013).

$\downarrow$ The production efficiency of newly built and planned gasification plants is growing. In addition to an increase in the unit capacity of gasifiers, currently built and planned systems reach their production capacity by integrating gasifiers.

$\checkmark$ The most intensive development of gasification technology has occurred in the region of Asia and Australia. In addition to China, the dynamic development of technology in: India, Malaysia, Japan, and South Korea is worth mentioning. 
$\checkmark$ The main direction in the now operating and planned gasification plants are chemical products. It is estimated that $25 \%$ of world ammonia production and $30 \%$ of world methanol production is produced using gasification processes. The concept of producing Synthetic Natural Gas (SNG) is also at its height.

- The prediction from 2010 regarding the development of the IGCC system in the US has not come true, as the emergence of available shale gas deposits radically changed the market conditions.

$\downarrow$ Currently, Japan (NEDO, MHPS - Mitsubishi Hitachi Power Systems, Osaka Coal Gen Corporation) is the leader in the field of energy production systems through coal gasification, where the IGCC technology is being intensively developed, also taking the $\mathrm{CO}_{2}$ separation option and fuel cell integration concept into account.

$\checkmark$ Coal dominates as a raw material for gasification processes.

$\checkmark$ In addition to the technological market leaders such as: Shell, GE/Texaco, Lurgi, ECUST U-GAS and MHPS, new developed technologies have appeared, among others, in China and Japan (CECO-Changzheng Engineering, MCSG -Northwest Research, SEDIN, EAGLE).

A breakthrough in the perception of gasification technology as part of the energy production system may be achieved by demonstrating coal gasification systems with fuel cells on an industrial scale. Advanced work in this area is implemented, among others, in Japan using the new gasification technology in the EAGLE Sano entrained bed gasifier, 2016. Work in this area

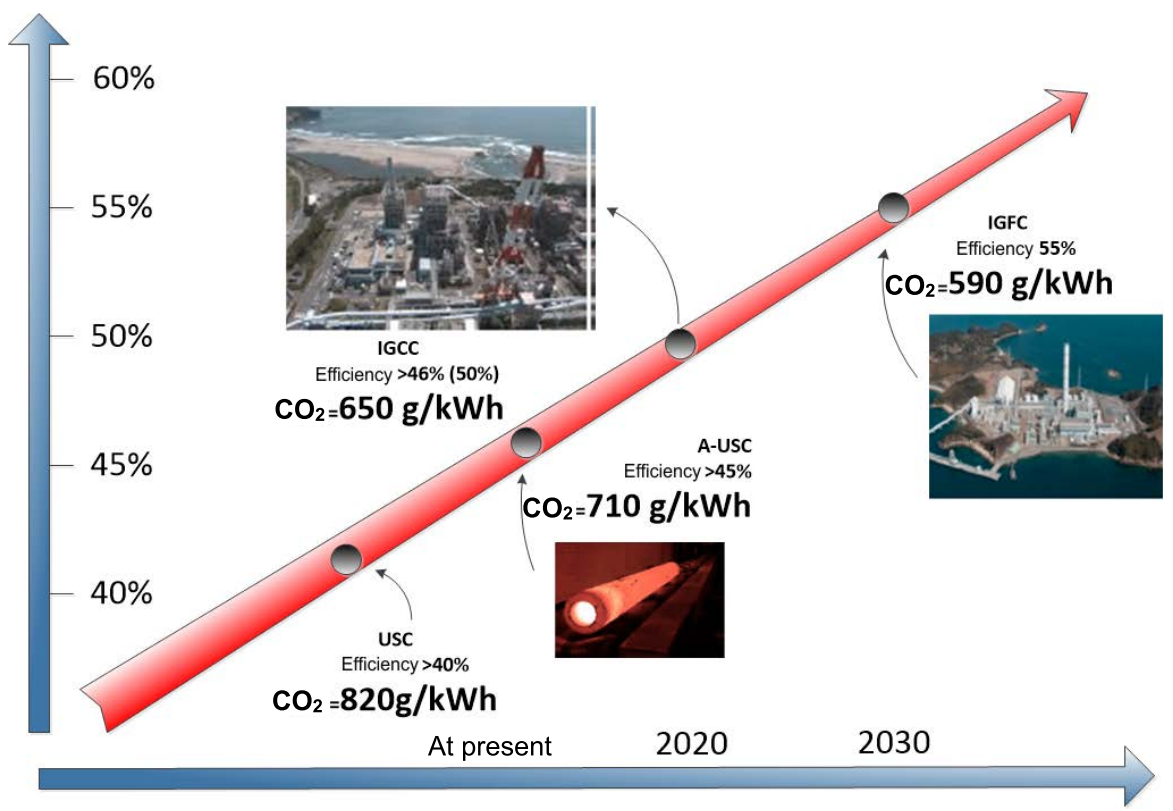

Fig. 2. The time perspective of the development of coal gasification technology for energy applications (Sano 2016) IGCC - Integrated Gasification Combined Cycle, IGFC - Integrated Gasification Fuel Cells, USC - Ultra-Supercritical, AUSC - Advanced Ultra-Supercritical

Rys. 2. Perspektywa czasowa rozwoju technologii zgazowania węgla dla zastosowań w energetyce 
is coordinated by NEDO (New Energy and Industrial Technology Development Organization). The time perspective of technology development is presented in Fig. 2.

\subsection{Waste gasification}

Thermal treatment of waste (combustion, gasification, pyrolysis) has a relatively short history. The beginning of the dynamic development of technology goes back to the 1990s, while in 2010 approx. 5 million tons of waste in the world was already subject to treatment (Fig. 3).

The leader in this field is Japan (Fig. 3), where right at the outset gasification was given priority as the most suitable process for both technological and environmental reasons.

Despite the long history of coal gasification technology development, this technology has been only recently applied to municipal and industrial waste processing. The main problem turned out to be the heterogeneous chemical composition of waste intended for gasification and the difficulty of preparing the appropriate its size distriubution.

Due to the fact that gasification supplies gas, the composition of which may be regulated by selecting the appropriate technology, two main directions of application of this technology may be distinguished: energy and chemical directions. The energy direction is currently dominant.

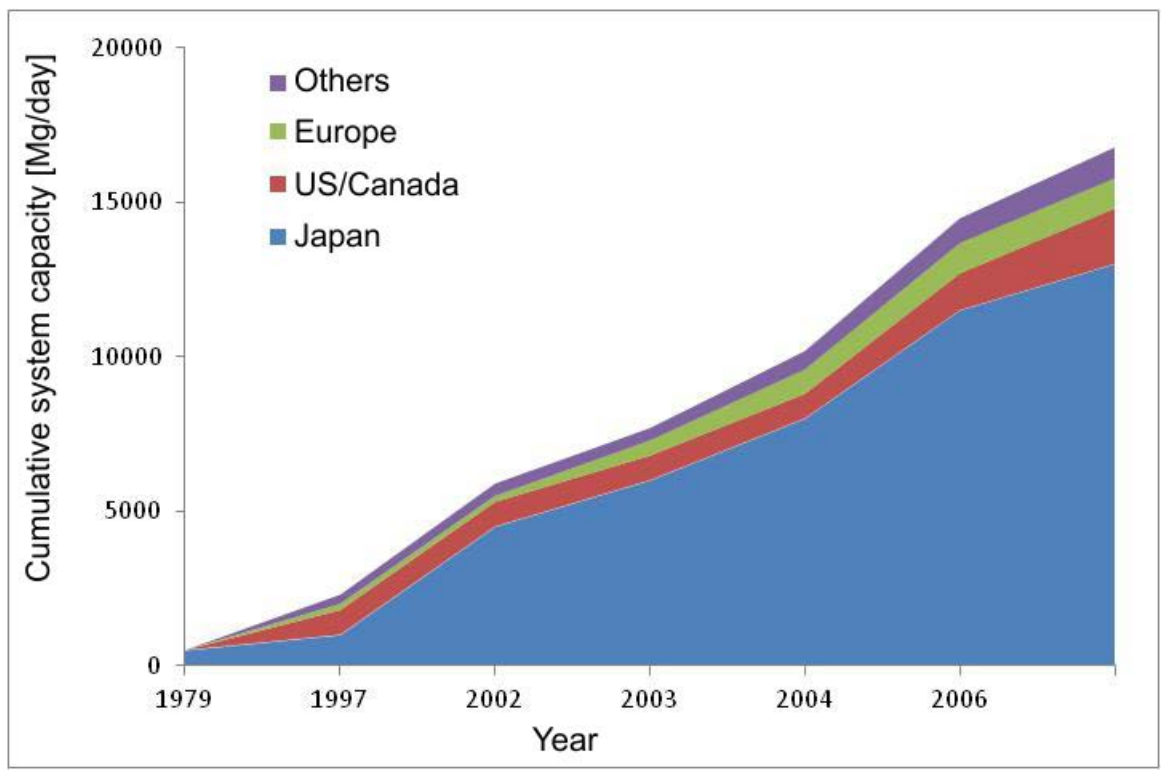

Fig. 3. World waste use in thermal waste treatment processes

Rys. 3. Światowe zużycie odpadów w procesach termicznego przekształcania 


\section{Gasification economics}

\subsection{The IGCC systems}

The concept of using coal gasification technology is best evidenced in the integrated gasification combined cycle (IGCC) consisting in the gasification of coal into gaseous fuel, which following its treatment is subject to combustion in a gas turbine. The waste gas heat is used for generating steam which drives the steam turbine. the air separation unit (ASU), gasification islands, gas cooling and purification system, gas turbine and heat recovery steam generator (HRSG) are the key elements of this system. Slag and sulfur or sulfuric acid are the by-products of the IGCC system. An example flowchart of the IGCC system is shown in Fig. 4. Examples of IGCC systems operating commercially are: Duke Energy systems (580 MWe, GE) or older systems: Wabash River (262 MWe, U-GAS/CB\&I), Tampa Electric (250 MWe), GE), and Nakoso (250 MWe, MHPS).

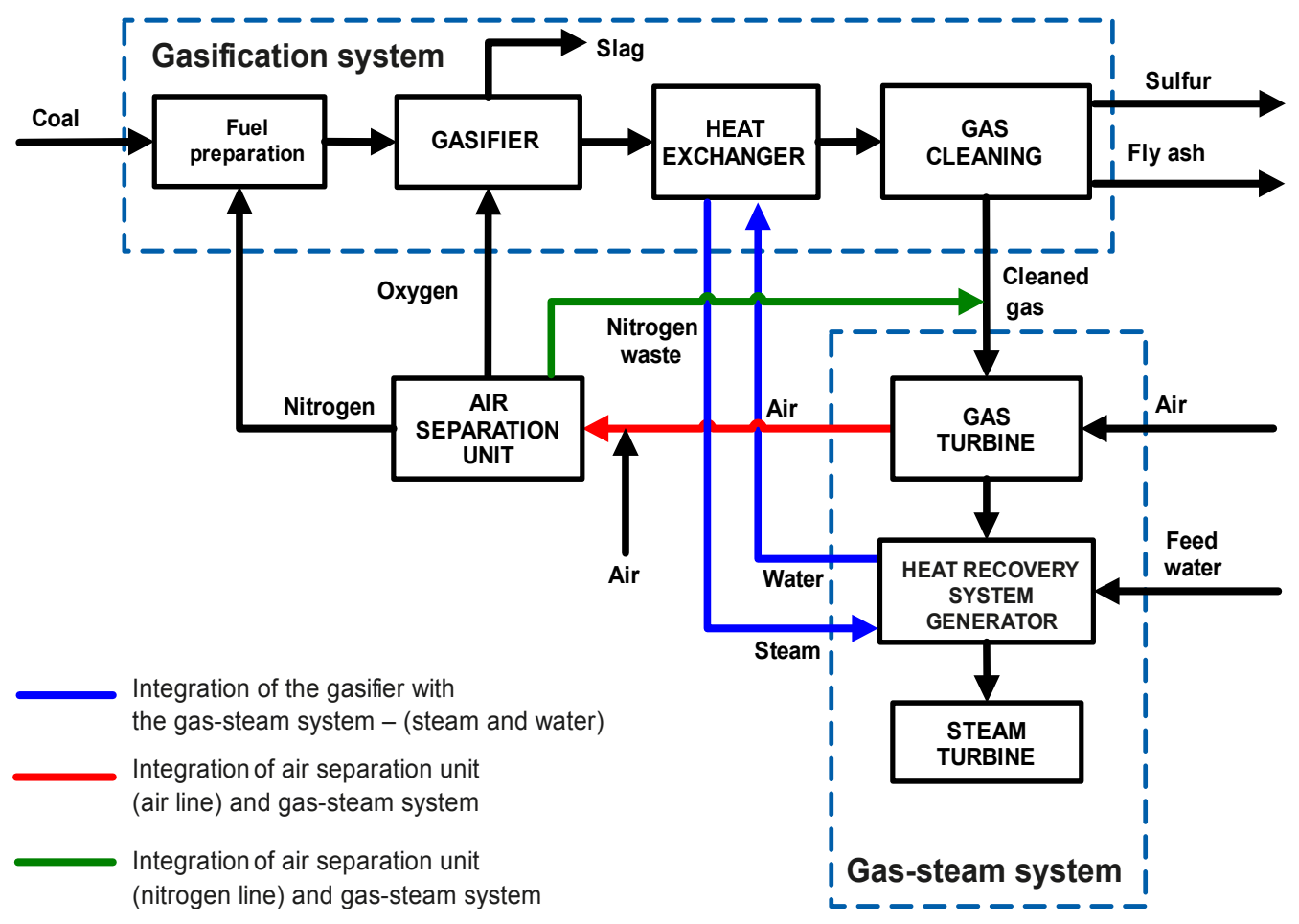

Fig. 4. Schematic diagram of the coal gasification system integrated with combined cycle (Coca)

Rys. 4. Schemat układu zgazowania węgla zintegrowanego z układem gazowo-parowym (Coca) 
The basic advantages of such solutions include:

$\downarrow$ High efficiency of electricity generation.

४ High fuel flexibility (including various coal grades, oil refining residues and biomass) with the possibility of automatic switching to oil or natural gas.

- Extremely low emission levels of harmful substances into the environment including the possibility of $\mathrm{CO}_{2}$ removal, with lower losses of electricity generation efficiency than in the case of classical combustion technologies is of particular importance. The same

TABLE 2. The potential of new technologies for improvement of efficiency and reduction of production costs in the IGCC systems. The IGCC system with $\mathrm{CO}_{2}$ capture (Current and Future... 2010)

TABELA 2. Potencjał nowych technologii dla poprawy sprawności i obniżenia kosztów produkcji w układach IGCC. Układ IGCC z wychwytem $\mathrm{CO}_{2}$

\begin{tabular}{|c|c|c|c|c|c|c|}
\hline Technology/operation & $\begin{array}{l}\text { Efficiency } \\
{[\% \mathrm{HHV}]}\end{array}$ & $\begin{array}{l}\text { Efficiency } \\
\text { increase* } \\
\text { (point \%) }\end{array}$ & $\begin{array}{l}\text { Total cost of } \\
\text { the system** } \\
(\mathrm{USD} / \mathrm{kW})\end{array}$ & $\begin{array}{l}\text { Increase in } \\
\text { total cost of } \\
\text { the system** } \\
(\mathrm{USD} / \mathrm{kW})\end{array}$ & $\begin{array}{l}\text { Energy cost } \\
\text { (cent/kWh) }\end{array}$ & $\begin{array}{l}\text { Increase* in } \\
\text { energy cost } \\
\text { (cent/kWh) }\end{array}$ \\
\hline Reference IGCC & 30.4 & 0.0 & 2718 & 0 & 11.48 & 0.0 \\
\hline The "F" class turbine & 31.7 & 1.3 & 2472 & -246 & 10.64 & -0.84 \\
\hline Dry fuel pump (dosing) & 32.5 & 0.8 & 2465 & -7 & 10.54 & -0.10 \\
\hline Capacity factor $85 \%$ & 32.5 & 0.0 & 2465 & 0 & 10.14 & -0.40 \\
\hline Hot gas cleaning/Selexol & 33.3 & 0.8 & 2425 & -40 & 10.00 & -0.14 \\
\hline $\begin{array}{l}\text { Hot gas cleaning/ } \\
\text { hydrogen membrane }\end{array}$ & 36.2 & 2.9 & 2047 & -378 & 8.80 & -1.20 \\
\hline $\begin{array}{l}\text { Advanced hydrogen } \\
\text { turbine, level } 1\end{array}$ & 38.0 & 1.8 & 1855 & -192 & 8.14 & -0.66 \\
\hline $\begin{array}{l}\text { Ion membrane }-\mathrm{O}_{2} \\
\text { production }\end{array}$ & 38.3 & 0.3 & 1724 & -131 & 7.74 & -0.40 \\
\hline $\begin{array}{l}\text { Advanced hydrogen } \\
\text { turbine, level } 2\end{array}$ & 40.0 & 1.7 & 1683 & -41 & 7.61 & -0.13 \\
\hline Capacity factor $90 \%$ & 40.0 & 0.0 & 1683 & 0 & 7.36 & -0.25 \\
\hline Total & & $\begin{array}{l}+9.6 \% \text { point } \% \\
(+32 \%)\end{array}$ & & $\begin{array}{l}-1035 \\
(-38 \%)\end{array}$ & & $\begin{array}{c}-4.12 \\
(-36 \%)\end{array}$ \\
\hline $\begin{array}{l}\text { Coal gasification } \\
\text { integrated with fuel cells }\end{array}$ & 56.3 & $\begin{array}{l}+26 \% \text { point } \% \\
+85 \%\end{array}$ & 1759 & $\begin{array}{c}-959 \\
(-35 \%)\end{array}$ & 7.45 & $\begin{array}{c}-4.03 \\
(-35 \%)\end{array}$ \\
\hline
\end{tabular}

* Increase in relation to the previous configuration.

** The total system costs relate to 2007 (January). 
applies to mercury removal. In addition, in the case of the IGCC systems, a significant (20-40\%) reduction in water consumption compared to traditional systems is possible.

The currently operating IGCC systems are characterized by net efficiency of electricity production at the level of $42 \%$, with a high gross efficiency at the level of $50 \%$ (without $\mathrm{CO}_{2}$ capture). The main reason for such a significant drop in efficiency is the high energy consumption of the process, related mainly to the production of oxygen in cryogenic separation systems. Energy consumption due to oxygen production covers up to $80 \%$ of the own needs of the IGCC systems. Therefore, one of the basic directions to improve the overall efficiency of the IGCC system is the development of new oxygen production technologies and the use of air-oxygen mixtures in the gasification process.

It should be emphasized that in the case of the IGCC technology there is a large development potential associated with the possibility of improving efficiency, resulting in, among others, the possibility of reducing energy intensity of the process (oxygen production) and the development of gasification technology and gas turbines. The possibilities of improving efficiency of the IGCC system are presented in Table 2. The reference value adopted is the reference efficiency of the system using $\mathrm{CO}_{2}$ capture. Presented new technologies, which may contribute to a significant increase in efficiency, are developed, among others, as part of the R\&D programs coordinated by the US Department of Energy and those related to gasification technology.

In the short term, a lot of interest in the development of the IGCC technologies has been aroused by new investments implemented in Japan and based on the MHPS technology. In the solution proposed by MHPS, the gasification process is carried out in an entrained flow gasifier with a dry fuel feed. The gasification agent is air, which means that the own consumption of electricity is lower and results in higher generation efficiency.

The MHPS technology is dedicated to electricity production using the IGCC systems. At present, after the positive results obtained in the Nakoso demonstration system, the construction of two 500 MWe IGCC systems (480 MWe net) in Japan with a guaranteed net efficiency at $48 \%$ is planned. The success of this investment both from the point of view of the efficiency of the process and its production economics may contribute to the popularization of the technology, also in our country.

Fig. 5 shows an example structure of investment costs of the IGCC system using the Shell gasification technology (oxygen gasification) (Cost and Performance... 2015).

In the case of outlays for the purchase of equipment, the largest investment costs are definitely related to the gasification system (gasification island and oxygen production), energy island and fuel preparation (preparation and transport) and gas treatment in the case of $\mathrm{CO}_{2}$ separation. $43 \%$ of the total investment outlays are items related to engineering and design as well as the assembly of the system (this item also includes the so-called incidental costs). The reduction of investment costs is seen as one of the basic conditions for the further development of gasification technology for energy applications. The largest potential in this area is in the areas of fuel preparation nodes, especially in the dosing area and gasification islands, in particular including oxygen production and synthesis gas cooling. Justified from the point of view of systems with 

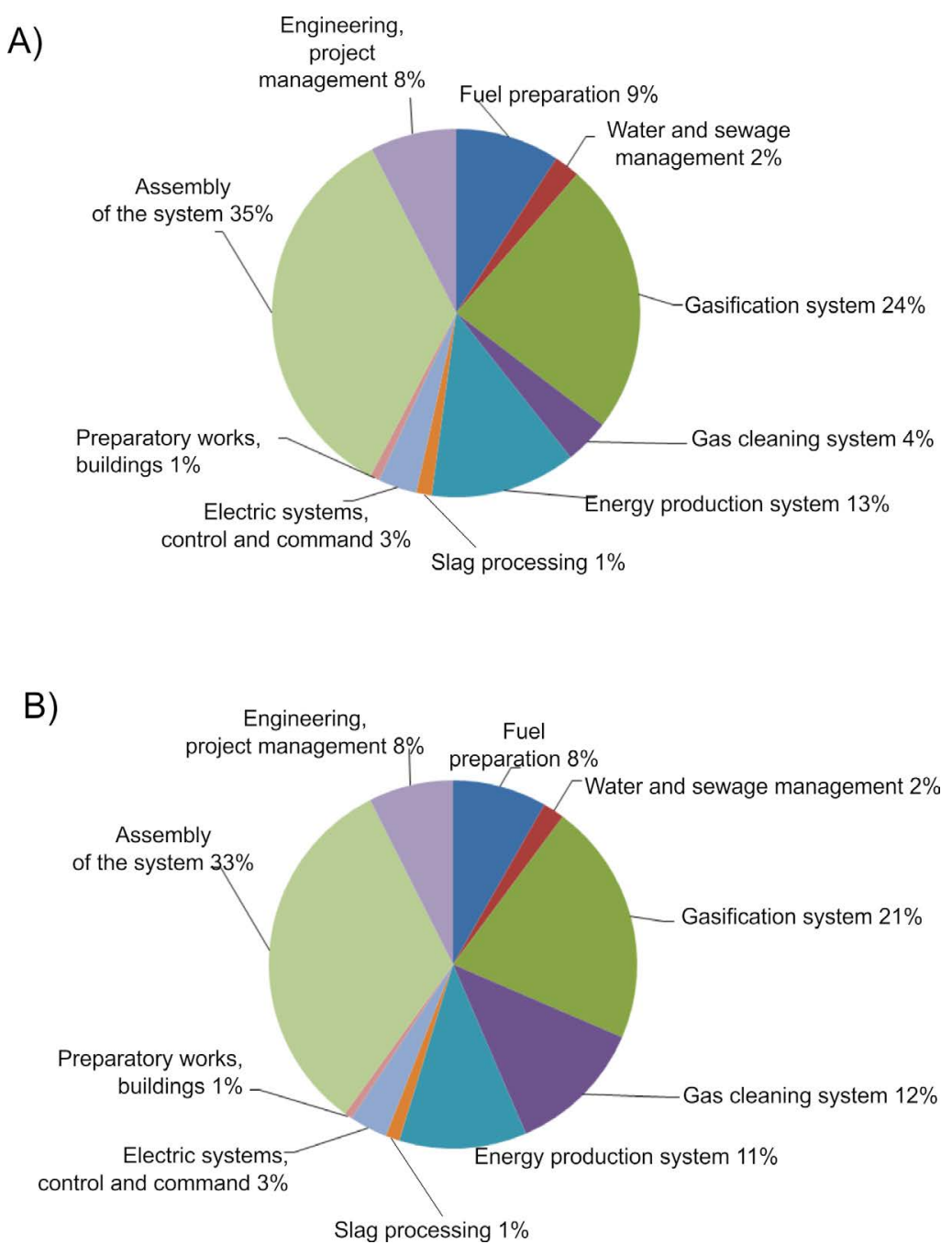

Fig. 5. Structure of investment outlays. The IGCC system with dry fuel feed, technology by Shell. A) without $\mathrm{CO}_{2}$ removal, B) with $\mathrm{CO}_{2}$ removal (Cost and Performance... 2015)

Rys. 5. Struktura nakładów inwestycyjnych. Układ IGCC z suchym doprowadzeniem paliwa, technologia Shell A) bez usuwania $\mathrm{CO}_{2}$, B) z usuwaniem $\mathrm{CO}_{2}$

$\mathrm{CO}_{2}$ separation, the introduction of gas cooling through direct water spraying allows investment costs of the gasification island to be reduced by up to $30 \%$. The huge impact of investment costs on the cost of production is shown in Fig. 6.

According to US data (Cost and Performance 2010, 2015), capital outlays for IGCC systems are USD 3,351/kWe (net installed capacity) and USD 4,917/kWe for systems without and with $\mathrm{CO}_{2}$ separation (technology by Shell) respectively, and are higher by 34 and $13 \%$ from outlays 


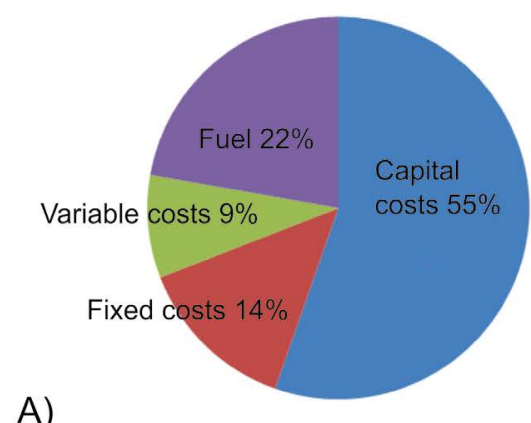

A)

Fig. 6. Structure of energy production costs A) and division of operating costs without capital and fuel costs B). The IGCC system with dry fuel feed without $\mathrm{CO}_{2}$ separation, technology by Shell (Cost and Performance... 2015)

Rys. 6. Struktura kosztów produkcji energii A) oraz podział kosztów operacyjnych bez kosztów kapitału i paliwa B). Układ IGCC z suchym doprowadzeniem paliwa bez separacji $\mathrm{CO}_{2}$, technologia Shell

for classic system operating on supercritical parameters, which with comparable production efficiency also results in higher energy production costs. Lower CAPEX and OPEX expenditures are key factors which may guarantee the success of the IGCC technology, undoubtedly offering the lowest environmental burden and highest development potential among the so-called clean coal technologies.

Analyzing the impact of the economic environment (market) on the attractiveness of the PC systems (Pulverized coal: coal combustion - pulverized coal fired generator), NGCC systems (Natural Gas Combined Cycle) and IGCC systems, the latter are the best choice at natural gas prices over PLN 43 /GJ (USD $1=$ PLN 3.7) and costs of $\mathrm{CO}_{2}$ emissions above $240 \mathrm{PLN} / \mathrm{t}$.

\subsection{Coal gasification for chemical products}

Currently, the most common application of coal gasification technology is the production of chemical substances, including liquid and gaseous fuels. This results from the need to preserve the independence of raw materials for industry in countries with large coal resources and limited resources of gas and oil. In addition, such technologies may be economically attractive when used for the production of chemicals.

In chemical systems, cheaper and simpler gasification systems are used, which, along with relatively low fuel costs boosts the attractiveness of such a solution. Currently, the most attractive direction for the use of gasification technologies is production of ammonia and methanol as semi-finished products for chemical synthesis and fuel production. 
The structure of investment costs for a methanol production system with a capacity of approximately 500,000 tons/year, using gasification technology in a entrained bed gasifier with dry fuel feed, is shown in Fig. 7. The structure of production costs, excluding financial costs, is presented in Fig. 8.

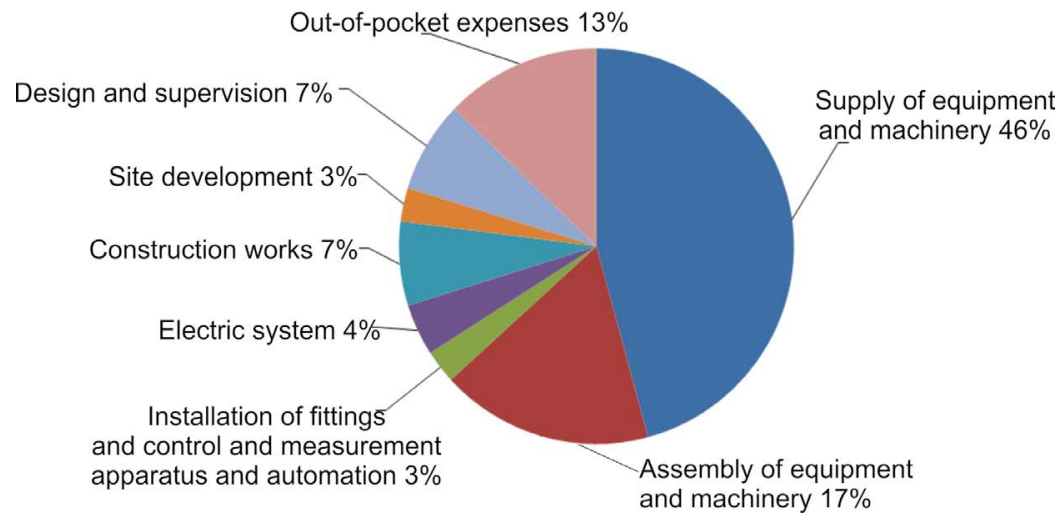

Fig. 7. Structure of investment outlays. Methanol production system, coal gasification in a dispersive gasifier with dry fuel feed (the system includes air separation and energy node for disposal of residual gases) (own source 2014)

Rys. 7. Struktura nakładów inwestycyjnych. Układ produkcji metanolu, zgazowanie węgla w reaktorze dyspersyjnym z suchym doprowadzeniem paliwa (układ obejmuje separacje powietrza oraz węzeł energetyczny do utylizacji gazów resztkowych)

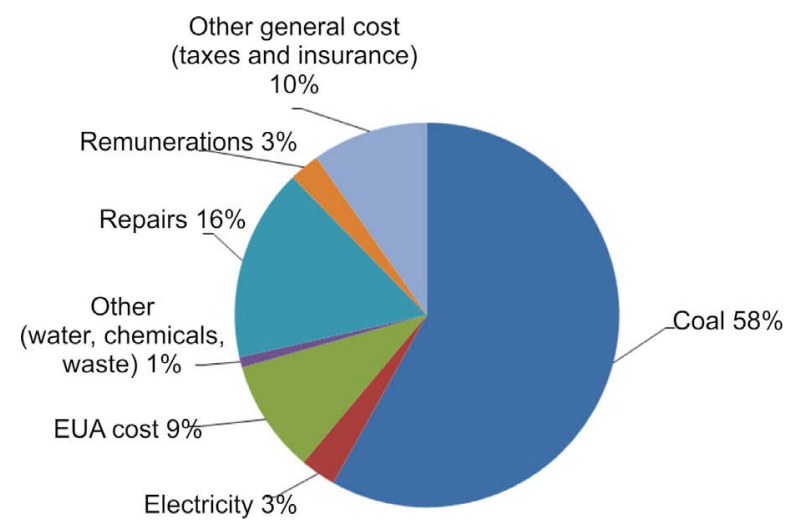

Fig. 8. Structure of production costs. Methanol production system, coal gasification in a dispersive gasifier with dry fuel feed (the system includes air separation and energy node for the disposal of residual gases).

The costs of $\mathrm{CO}_{2}$ emissions at the level of $30 \mathrm{PLN} / \mathrm{t}$ have been included (own source 2014)

Rys. 8. Struktura kosztów produkcji. Układ produkcji metanolu, zgazowanie węgla zgazowanie węgla w reaktorze dyspersyjnym z suchym doprowadzeniem paliwa (układ obejmuje separacje powietrza oraz węzeł energetyczny do utylizacji gazów resztkowych). Uwzględniono koszty emisji $\mathrm{CO}_{2}$ na poziomie $30 \mathrm{zl} / \mathrm{t}$ 
In the case at hand, the costs of producing a unit amount of methanol are clearly below market prices (2014). The analysis of changes in methanol market prices for the last 4 years shows that in 2016 such prices were comparable to the estimated production costs (Fig. 9). In other periods, the production cost for 2014 accounted for 50 to $80 \%$ of stock prices.

Methanex European

Posted Contract Price (MEPCP)

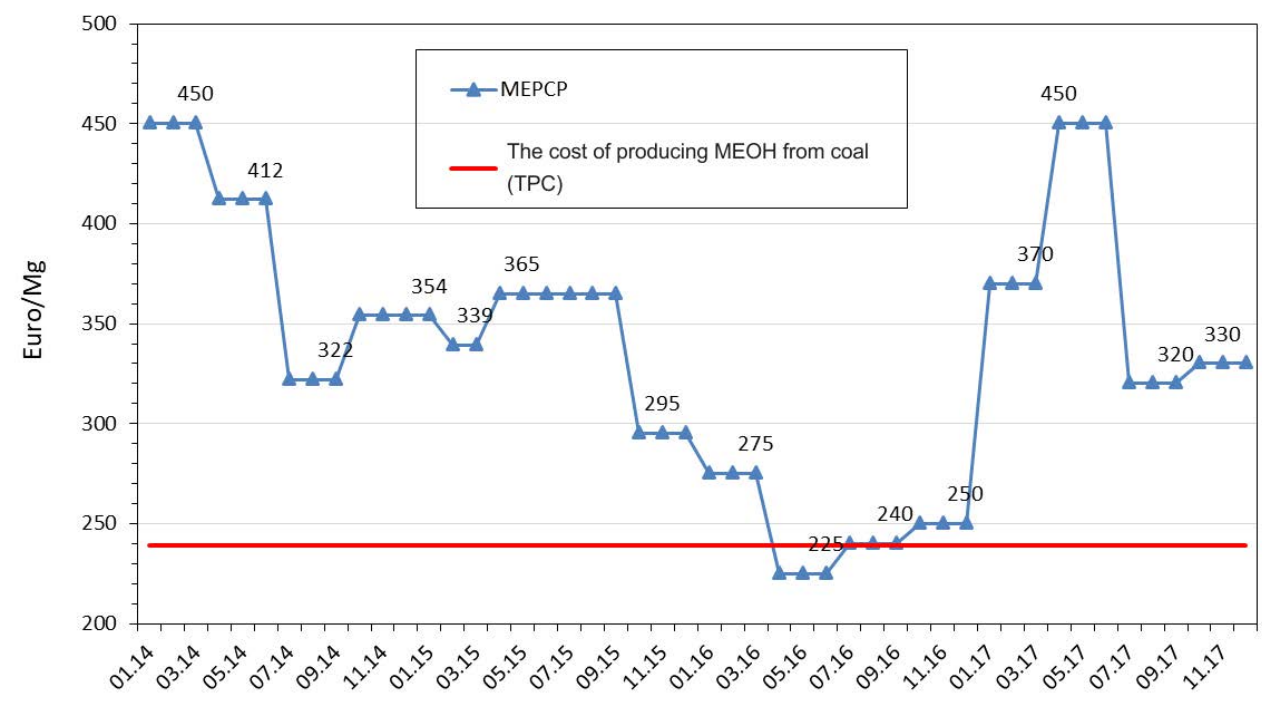

Fig. 9. Changes in methanol prices on the market in 2014-2017 (https://www.methanex.com/our-business/pricing) against the background of manufacturing costs (calculation year 2014)

Rys. 9. Zmiany cen metanolu na rynku w latach 2014-2017 na tle kosztów wytworzenia (rok obliczeniowy 2014)

All of the above affects the relatively high profitability of this type of investment. The calculations made (status as of 2014) showed that the NPV for the analyzed system amounted to PLN $777 \mathrm{~m}$ (operation period being 30 years) with IRR indicators and a payback period of 12.7 and 15.6 years, respectively.

\subsection{Gasification of municipal and industrial waste}

In the case of waste gasification, the most advanced solution is the application of this process for energy recovery in the systems categorized as thermal waste treatment systems. 
The chemical direction may thus seem attractive, nonetheless it is still in the development phase.

The analysis of the market of gasification technologies used on an industrial scale (the processing scale of about 120,000 tons of waste per year) would suggest that the following are currently leaders: Alter NRG Westinghouse Plasma Corporation (Alternrg), CHO Power (Cho-Power), Enerkem (Enerkem), Foster Wheeler (GlobSyngas), JFE High Temperature Gasifying and Melting System (Jfe-steel), Leveraged Green Energy Gasplasma -LGE (Lgefund), and Nippon Steel \& Sumikin Engineering -NSENGI (Nippon Steel and Sumikin Engineering).

Among the listed technologies, gasifiers with a structure and principle of operation similar to a large metallurgical furnace offered by, among others, NSENGI and JFE are most widely used. The gasifiers also allow for the utilization of hazardous and toxic waste. They are most flexible in terms of the size of the fraction directed to the gasifier. The final product is steam with parameters allowing electricity in a steam turbine block to be generated. The structure of investment and operating costs for the waste management system are presented in Figures 10 and 11 , respectively.

The financial analysis of this type of technology applied in the electricity production by gasification of municipal and industrial waste shows its unacceptable profitability from the point of view of the investor implementing the project. This is mainly attributable to a overly low level of revenues in relation to the level of necessary investment outlays and operating costs. The

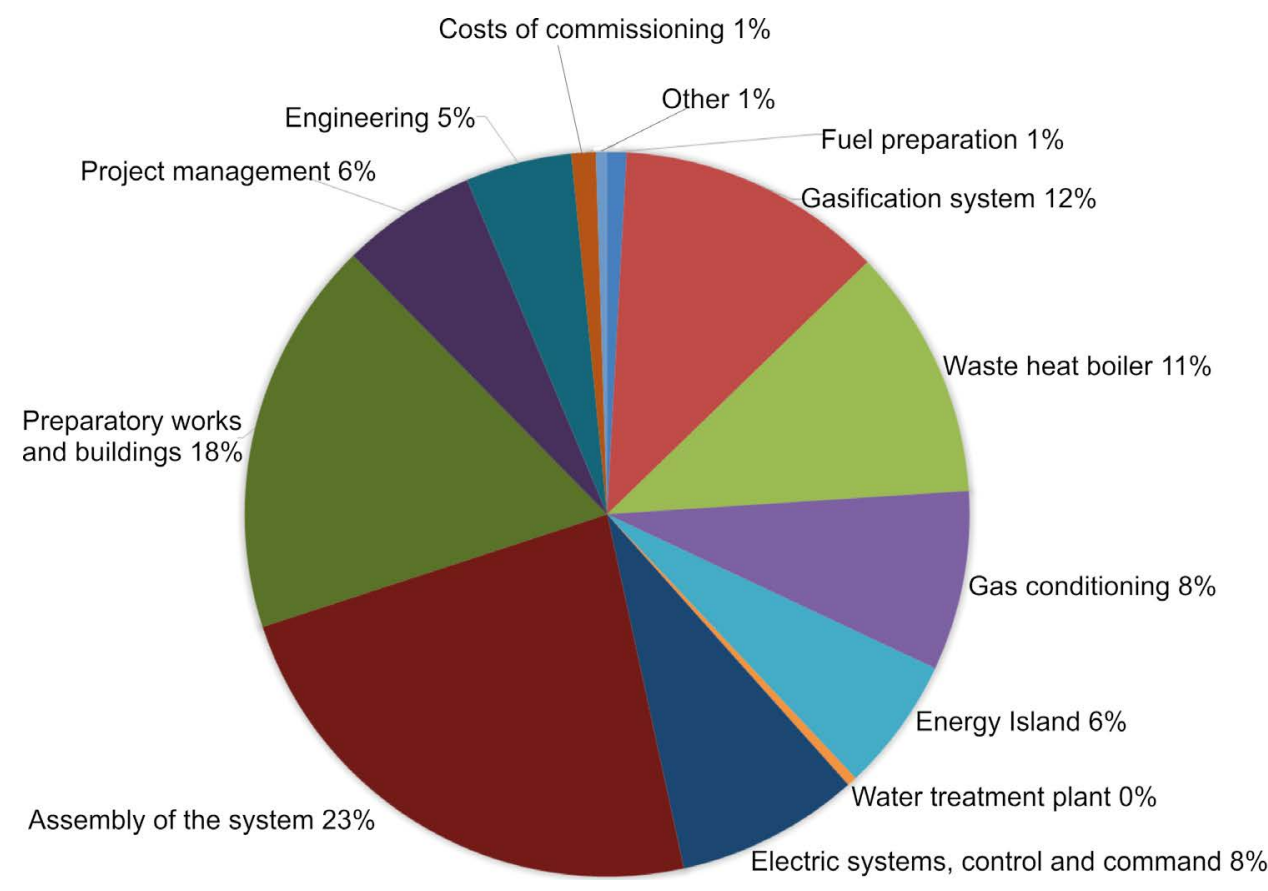

Fig. 10. Structure of investment outlays for waste management systems

Rys. 10. Struktura nakładów inwestycyjnych dla układów utylizacji odpadów 


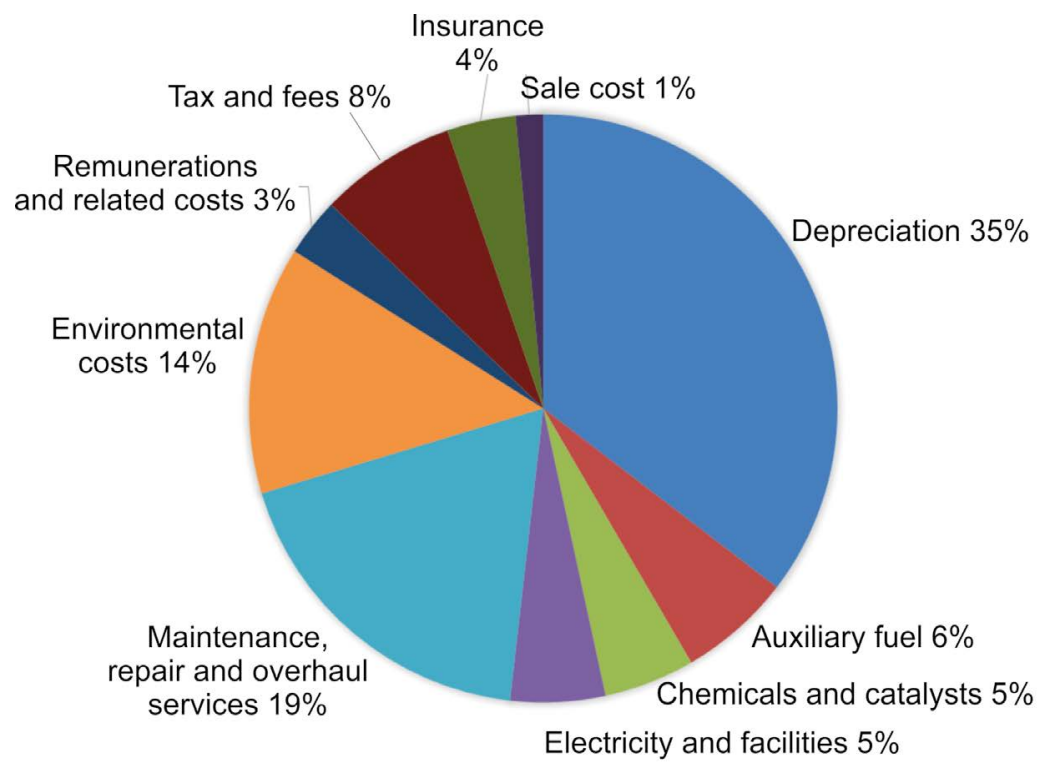

Fig. 11. The structure of operating costs for waste management systems

Rys. 11. Struktura kosztów operacyjnych dla układów utylizacji odpadów

estimated financing gap rate will be NPV $=-$ PLN 442.8 million with investment outlays in the amount of PLN 500 million. From the analyzed factors, the most sensitive project shows changes in the level of investment outlays, prices of municipal waste and the degree of utilization of the system.

\section{Technical and economic conditions for the implementation of gasification technology}

The use of gasification technology seems to be very attractive as it allows solid fuel, both coal and waste, to be transformed into combustible gas, which after the adjustment of its composition may also be used for the production of hydrogen, methanol, and other chemicals. For this reason, the use of gasification technology is implemented in the world in the following directions:

$\checkmark$ Electricity production in steam systems in the case of waste and in the IGCC systems (in the future the IGFC) for coal.

$\checkmark$ Polygeneration gasification, binding the production of electricity with chemical production directed to hydrogen, methanol, olefins, motor fuels, or substitute for natural gas.

$\downarrow$ Gasification for the needs of the chemical industry in order to substitute natural gas. 
These directions are also of interest to several large industrial entities in Poland. Over the past 15 years several very advanced technical and economic studies have been conducted both for the energy and chemical industries, though unfortunately, no decision has been made yet as to undertaking the investment process.

It may seem that while construction of the first commercial gasification system in Poland poses a certain risk, it would be quite necessary to look at the reasons for the lack of investment decisions.

In the case of energy, environmental requirements regarding dust, $\mathrm{NO}_{\mathrm{x}}$, and $\mathrm{SO}_{\mathrm{x}}$ emissions also include the emission of mercury and carbon dioxide. At the same time, technological water is becoming an increasingly expensive component of operating costs. For this reason, gasification technology, which boasts both lower water consumption and the easier and less expensive elimination of pollutants, is very attractive. In addition, new solutions offered on the market guarantee high efficiency of electricity generation.

However, financial aspects, including implementation costs and operational reliability are the decisive factor for the development of the IGCC technology. A particularly sensitive element may be the oxygen production node and the development of new fuel regulating systems. The development of the IGCC technology as shown on the basis of the Japan experience indicates its huge potential, from solutions already available for sale, to highly efficient systems using fuel cells.

Despite such potential opportunities, however, the costs of electricity generation in IGCC systems are still higher than the production costs in modern steam units. This involves two key factors: the scale of gasification technology and CAPEX and OPEX expenditures. The currently used commercial gasification units have a capacity of $250 \mathrm{MWe}$, while the standard for steam units is $1000 \mathrm{MWe}$. At the same time, the unit CAPEX expenditures are $20-30 \%$ higher depending on the estimation.

As for the current state of development of IGCC systems (working commercial systems), their application becomes more effective than that of classic coal fired power unit and combined gas systems for natural gas where gas prices and $\mathrm{CO}_{2}$ emission costs exceed PLN 43/GJ and PLN 240/t of $\mathrm{CO}_{2}$ respectively.

As for the case of use of coal gasification for chemical production, the situation is entirely different. The European Union has only $0.9 \%$ of global documented natural gas resources. It is worth emphasizing that in 2010-2011 the level of documented natural gas resources in the world grew by $6.3 \%$, and in the case of the EU, it decreased by approx. $22 \%$. One may conclude that the European Union countries will be increasingly dependent on gas supplies from non-European countries, including countries with a high political risk. In Poland, there are no prospective natural gas resources available. Analyses show that hydrogen production for chemical synthesis in nitrogen and methanol plants is economically viable. In China, over 200 million tons of coal is processed annually by such means into chemical products. Thus, the technology is mature and economically effective. It may seem that only strategic decisions at the state level may help to overcome risk assessment barriers of the first such investment.

In the case of waste gasification, the only factor justifying investment decisions is the formal and legal necessity of waste treatment or its combustible fractions. Therefore, it is not an under- 
taking of a typical business nature. The CAPEX and OPEX expenditures will have to be covered by the waste supplier as a consequence of the impossibility of storage of such waste. Taking an investment decision is, of course, related to the choice of waste conversion technology and the direction of use of the final product. Undoubtedly, the only direction which prevails at present is the energy one, while the chemical direction remains in the phase of commercial tests. The unit cost of treatment of 1 ton of waste using gasification technology is PLN 300-600/ton.

\section{References}

CHMIELNIAK, T. and ŚCIĄŻKO, M. 2003. Co-gasification of biomass and coal for methanol synthesis. Applied Energy Vol. 74, pp. 393-403.

ChMielniaK, T. 2014. Simulation studies of hydrogen production technologies in respect of $\mathrm{CO}_{2}$ emissions, in the cycle - coal mining, transport and processing. Gliwice: Wyd. Politechniki Śląskiej.

COCA, M.T. Elcogas; Integrated gasification combined cycle technology: IGCC. Its actual application in Spain: ELCOGAS. Puertollano, Elcogas S.A., Club Español de la Energía.

Cost and Performance Baseline for Fossil Energy Plants Volume 1b: Bituminous Coal (IGCC) to Electricity Revision 2b - Year Dollar Update, July 31, 2015; DOE/NETL-2015/1727.

Cost and Performance Baseline for Fossil Energy Plants Volume 1: Bituminous Coal and Natural Gas to Electricity, Revision 2, November 2010; DOE/NETL-2010/1397.

Current and Future Technologies for Gasification-Based Power Generation, Volume 2: A Pathway Study Focused on Carbon Capture Advanced Power Systems R\&D Using Bituminous Coal, October 7, 2010; DOE/NETL-2009/1389.

HIGMAN, C. 2013. State of the Gasification Industry - the Updated Worldwide Gasification Database. Gasification Technology Conference, Colorado Springs.

Higman, C. 2017. GSTC Syngas Database: 2017 Update. Gasification \& Syngas Technologies Conference, Colorado Springs.

SANO, H. 2016. NEDO's Clean Coal Technology Development for reduction of $\mathrm{CO}_{2}$ emissions; NEDO, 2016-06-12.

ŚCIĄŻKO, M. and CHMIELNiAK, T. 2012. Cost Estimates of Coal Gasification for Chemicals and Motor 'Fuels [In:] Yongseung Yun (ed.): Gasification for Practical Applications, InTech DOI: 10.5772/48556 [Online] http://www.intechopen.com/ books/gasification-for-practical-applications/cost-estimates-ofcoal-gasification-for-chemicals-and-motor-fuels [Accessed: 2018-03-01].

Methanex [Online] https://www.methanex.com/our-business/pricing [Accessed: 2018-03-01].

Alternrg [Online] http://www.alternrg.com/ [Accessed: 2018-03-01].

Cho-Power [Online] http://www.cho-power.com/en/ [Accessed: 2018-03-01].

Enerkem [Online] http://enerkem.com/about-us/technology/ [Accessed: 2018-03-01].

GlobSyngas [Online] http://www.gasification-syngas.org/uploads/eventLibrary/14.3_Foster_Wheeler_ Andy_Allen.pdf [Accessed: 2018-03-01].

Jfe-steel [Online] http://www.jfe-steel.co.jp/en/research/report/016/pdf/016-05.pdf [Accessed: 2018-03-01]. Lgefund [Online] http://gefund.net/ [Accessed: 2018-03-01].

Nippon Steel and Sumikin Engineering [Online] https://www.eng.nssmc.com/english/business/ environment/e_01 [Accessed: 2018-03-01]. 


\title{
Dylematy inwestycyjne wdrażania technologii zgazowania w Polsce
}

\author{
Streszczenie
}

Technologia zgazowania postrzegana jest często jako synonim czystego i efektywnego przetwórstwa paliw stałych do gazu palnego zawierającego głównie tlenek węgla i wodór - dwa podstawowe składniki gazu syntezowego. Możliwość stosunkowo łatwego i taniego oczyszczania gazu oraz komponowania jego składu pozwala na szerokie zastosowanie technologii w energetyce i przemyśle chemicznym. W energetyce gaz może być bezpośrednio użytkowany do wytwarzania ciepła i energii elektrycznej w układach siłowni parowej, względnie w układach gazowo-parowych. Dodatkową zaletą jest możliwość skutecznego i relatywnie taniego usuwania $\mathrm{CO}_{2} \mathrm{z}$ układu. W chemii gaz syntezowy może służyć do wytwarzania wodoru, metanolu, benzyn syntetycznych i innych produktów chemicznych. Surowcem dla zgazowania może być zarówno miał węglowy, jak również paliwa niskojakościowe, w tym muły węglowe, palne frakcje wydzielane z odpadów komunalnych i odpadów przemysłowych. Mimo tak szerokich możliwości zastosowania technologii zgazowania oraz jej niewątpliwych zalet, podejmowanie decyzji inwestycyjnych obarczone jest ciągle dużą niepewnością.

W artykule przedstawiono główne kierunki zastosowania technologii zgazowania i przeanalizowano ich efektywność ekonomiczną. W tym kontekście omówiono istotne uwarunkowania przemysłowego wdrożenia tej technologii.

SŁoWA KLUCZOWE: zgazowanie, technologie zgazowania, węgiel 
